logos_i_ethos_2020_(52), s. 107-120

DOI: http://dx.doi.org/10.15633/lie.3579

Jan Słomka

ORCID: 0000-0002-1404-5109

Uniwersytet Śląski

\title{
Zagadnienie cielesności w ujęciu Emmanuela Lévinasa: rozkosz erotyczna i pieszczota
}

Niniejsza praca dotyczy problematyki cielesności, w szczególności tego, jaka jest różnica, i czy w ogóle istnieje różnica między cielesnością człowieka a cielesnością innych istot. $\mathrm{Z}$ perspektywy fizyki, chemii, nauki nowożytnej w ogólności, ta różnica jawi się tylko jako różnica poziomu skomplikowania. W szczególności te pytania można postawić $\mathrm{w}$ odniesieniu do doznań zmysłowych: czy są one całkowicie rozkładalne na czynniki pierwsze według paradygmatu nauk nowożytnych? Czy zatem konstruowane przez człowieka czujniki, sensory i oparte na nich generatory wrażeń

Ks. prof. dr hab. Jan Słomka - pracownik naukowo-dydaktyczny Instytutu Nauk Teologicznych Uniwersytetu Śląskiego w Katowicach, wykładowca patrologii w Wyższego Seminarium Duchownego w Łodzi. Autor monografii: Nowe proroctwo: historia i doktryna monoteizmu, Katowice 2007; Wczesnochrześcijańskie nazwy chrztu, Katowice 2009; Historia duchowości: czas ojców Kościoła, Katowice 2016; Wprowadzenie do teologii katolickiej, Katowice 2018. Ponadto autor kilkudziesięciu artykułów naukowych publikowanych między innymi w „Śląskich Studiach Teologiczno-Historycznych" w Katowicach. Jego zainteresowania koncentrują się przede wszystkimi na patrologii oraz historii i teologii duchowości. Obecnie przygotowuje publikacje o teologii papieża Franciszka oraz filozofii Emmanuela Lévinasa jako ancilla theologiae.

zmysłowych mogą całkowicie zasymulować międzyludzkie doznania zmysłowe? Ten kontekst podyktował wybór tematu i ukierunkowanie analizy tekstu Emmanuela Lévinasa. Przedstawimy myśl Lévinasa odnośnie do jednego, ale wyjątkowego, doświadczenia zmysłowego: rozkoszy erotycznej, pieszczoty. Zwrócimy uwagę na to, jak francuski filozof umieszcza to ludzkie doświadczenie w swojej antropologii i teorii 
poznania oraz w jaki sposób je analizuje. W ramach konkluzji zderzymy przedstawione badania Lévinasa $z$ perspektywą nauki nowożytnej oraz spróbujemy zastanowić się nad ich przydatnością dla chrześcijańskiej teologii moralnej.

\section{Antropologia}

Człowiek jest ciałem. Zmysłowa cielesność jest naszym człowieczeństwem. Lévinas stoi na antypodach antropologii pokartezjańskiej, która postrzega człowieka dualistycznie, ciało ludzkie traktuje jako pewną zewnętrzność i w tymże ciele poszukuje punktu łączącego to zewnętrzne ciało z prawdziwym, duchowym człowieczeństwem (cogito, ja) ${ }^{1}$. Antropologię Lévinasa można opisać w kategoriach arystotelesowskich: ciało jest materią, a dusza formą, która przenika całą tę materię i nadaje jej życie. Również uznanie pierwszorzędnej roli zmysłów w strukturze poznania łączy Lévinasa z Arystotelesem. Na pewno jest to antropologia żydowska, starotestamentalna. Człowiek jest ciałem, czyli nasza cielesność we wszystkich jej przejawach jest naszym człowieczeństwem. Dla porządku dodajmy: te stwierdzenia nie mają nic wspólnego z materializmem nowożytnym, z antropologią redukującą człowieka do materii. Przedstawione poniżej analizy pozwolą, mam nadzieję, lepiej zrozumieć tę zasadniczą różnicę.

\section{Rozkosz}

Przeżycie erotycznie jest rozkoszą. Ale aby zrozumieć, jakiego znaczenia nabiera $\mathrm{w}$ myśli Lévinasa to skądinąd oczywiste stwierdzenie,

1 Przedstawiliśmy tutaj - dla uwypuklenia kontrastu - skrajnie uproszczony opis antropologii pokartezjańskiej, (dlatego dodaliśmy przedrostek po-), gdyż nie jest naszym celem głębsza analiza porównawcza antropologii Lévinasa i Kartezjusza. Należy jednak odnotować, że Lévinas często do Kartezjusza się odwołuje. Nawet w kwestii relacji cielesności i myśli, zmysłowości i wiedzy o ideach Lévinas znajduje u Kartezjusza ciekawe idee, choć jednocześnie podkreśla, że „nie zgadza się z Kartezjuszem co do natury tej więzi” między cielesnością a rozumnością. Zob. E. Lévinas, Inaczej niż być lub ponad istotą, tłum. P. Mrówczyński, Warszawa 2000, s. 132-133. 
trzeba cofnąć się do jego analiz poświęconych rozkoszy jako takiej. Rozkosz stanowi istotny element naszego człowieczeństwa. Jest ona dobrym, pięknym, stanem życia człowieka, niemal synonimem życia: człowiek przebywa u siebie, rozkoszuje się. Rozkosz sama w sobie nie jest podejrzana. Kojarzone z ascetyką chrześcijańską sformułowanie "grzeszna rozkosz" jest od Lévinasa jak najdalsze. Filozof poświęca jej m.in. cały punkt w Całości i nieskończoności zatytułowany Życie jako rozkoszowanie się ${ }^{2}$. Pojęcie spełnienia opisuje w następujący sposób:

Żyjemy dobrą strawą, powietrzem, światłem, widokami, pracą, ideami, snem itd. [...] W pewnej mierze są one zawsze przedmiotami rozkoszowania się, używania, przedmiotami, które odwołują się do naszego „smaku”.

Przedstawiając w ten sposób życie człowieka, Lévinas wychodzi poza logikę celowości charakterystyczną m.in. dla Arystotelesa. Przedmioty używane są nie tylko i nie przede wszystkim środkami do uzyskania jakiegoś celu, ale przedmiotami rozkoszy. Nie są też „rzeczami poręcznymi w Heideggerowskim sensie terminu"4. Dotyczy to zwłaszcza jedzenia, chleba. Rozkosz nie jest dodatkiem do życia, ale samą esencją życia ludzkiego. Tak samo, w opozycji do Arystotelesa, który pisał o potrzebie poznania jako początku filozofii, i Husserla, który wskazywał na przedstawienie i na intencjonalność nakierowaną na przedmiot jako akt źródłowy poznania, Lévinas wskazuje na życie, doznanie zmysłowe, w tym rozkosz zmysłową, jako doświadczenie źródłowe, początek filozofii.

Rozkoszowanie jest takim właśnie żywieniem się aktu samą swą aktywnością. Żyć chlebem nie znaczy przedstawiać sobie chleb ${ }^{5}$. Levinas rozwija tę polemikę dalej, w rozdziale poświęconym twarzy i zmysłowości ${ }^{6}$. Zanim Lévinas przystąpi do analizy spotkania Innego, wskazuje

2 E. Lévinas, Całość i nieskończoność: esej o zewnętrzności, tłum. M. Kowalska, Warszawa 1998, s. 118.

3 E. Lévinas, Całość i nieskończoność..., dz. cyt., s. 118.

4 E. Lévinas, Całość i nieskończoność..., dz. cyt., s. 119.

5 Zob. E. Lévinas, Całość i nieskończoność..., dz. cyt., s. 119.

6 Zob. E. Lévinas, Całość i nieskończoność..., dz. cyt., s. 118-120. 
na pierwotność i własną specyfikę wrażenia zmysłowego, rozkoszowania się, które będąc samym życiem, jest wcześniejsze od widzenia. Nie chodzi o widzenie widzenia - stosunek życia do jego własnej zależności od rzeczy polega na rozkoszowaniu się, które jako szczęście jest niezależnoś$\mathrm{cią}^{7}$. Wrażenie, rozkosz nie jest intencjonalnością nakierowaną na siebie samego. Rozkosz jest wrażeniem, a nie doświadczeniem o strukturze intencjonalnej. Myśliciel odpiera krytykę wartości poznawczej wrażenia wynikającą z ustanowienia intencjonalności jako fundamentu poznania:

Ta krytyka wrażenia nie uwzględnia poziomu, na którym życie zmysłowe przeżywamy jako rozkoszowanie się. [...] Zmysłowość nie jest obiektywizacją w zalążku. Tym, co charakteryzuje wrażenia, jest $\mathrm{z}$ istoty zdolne do zaspokojenia rozkoszowanie się .

A więc wrażenie zmysłowe, przede wszystkim rozkoszowanie się, nie ma struktury intencjonalnej oraz nie jest przedracjonalnym początkiem, jakby wstępnym w porównaniu z jakoby bardziej zaawansowaną obiektywizującą racjonalnością. Jest samodzielnym, niejako pełnoprawnym doświadczeniem źródłowym naszego człowieczeństwa i naszego poznania: „sens rozkoszowania się - które nie mieści się w schemacie obiektywizacji i widzenia - nie wyczerpuje się w określaniu widzialne-

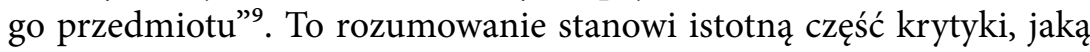
Lévinas kieruje pod adresem obiektywizującej ontologii, zaczynającej od skierowania intencjonalności, uwagi, poznania na przedmiotowość, choćby i siebie samego jako przedmiot, która to przedmiotowość uzurpuje sobie prawo do pokrywania się z samym byciem bytów. Jest to też przygotowanie teoriopoznawcze głównego tematu francuskiego filozofa: twarzy, innego człowieka, który objawia się zupełnie inaczej.

7 Zob. E. Lévinas, Całość i nieskończoność..., dz. cyt., s. 118.

8 E. Lévinas, Całość i nieskończoność..., dz. cyt., s. 218-219.

9 E. Lévinas, Całość i nieskończoność..., dz. cyt., s. 221. 


\section{Twarz Innego}

Przypomnienie tego sedna myśli Lévinasa jest niezbędne do dobrego umocowania naszego tematu. Otóż Całość i nieskończoność, jak uznaje to sam autor, jest esejem o zewnętrzności, czyli o innym człowieku. Inny człowiek objawia mi się przede wszystkim poprzez swoją twarz. Tego kluczowego dla Lévinasa wyrażenia nie należy rozumieć metaforycznie. Jemu chodzi o zmysłowe doświadczenie: oto przede mną stoi inny człowiek, który patrzy na mnie i mówi. O tej relacji pisze wielokrotnie w całym swoim dziele oraz poświęca jej część trzecią Całości i nieskończoności: Twarz i zewnętrzność. Pokazuje, że choć twarz jest w swej cielesności doświadczana poprzez zmysły oraz intencjonalnie, jej pierwotne objawienie jest inne. Twarz nie jest przedmiotem, lecz objawieniem bytu transcendentnego, czyli człowieka:

Jeżeli byt transcendentny zrywa ze zmysłowością, jeżeli jest otwarciem we właściwym sensie, jeżeli widząc go, widzimy samą otwartość bycia, znaczy to, że nie widzimy jego kształtów i nie możemy go wypowiedzieć ani w terminach kontemplacji, ani w terminach praktyki. Jest twarzą, jego objawienie jest słowem ${ }^{10}$.

Zmysłowe oraz intencjonalne w swym zewnętrznym kształcie doświadczenie twarzy rozrywa zmysłowość doświadczenia. Nie jest zmysłowe i nie jest doświadczeniem. Jest jednym wyjściem poza immanencję, jedyną transcendencją. Oczywiście mogę zacząć obserwować twarz jako obiekt, ale to jest wtórne.

\section{Erotyka - poza twarzą}

Czwarta, przedostatnia część Całości i nieskończoności, zatytułowana Poza twarza ${ }^{11}$, w większej części jest poświęcona Erosowi. Eros, zbliżenie erotyczne, jest osobnym, pierwotnym i całkowicie ludzkim sposo-

10 E. Lévinas, Całość i nieskończoność..., dz. cyt., s. 221.

11 E. Lévinas, Całość i nieskończoność..., dz. cyt., s. 301-303. 
bem spotkania, właśnie poza twarzą, ale wcale $\mathrm{z}$ tego powodu nie mniej ludzkim $^{12}$. Lévinas pisze:

Musimy opisać poziom, który jednocześnie zakłada i transcenduje epifanię Innego w twarzy, poziom, na którym Ja przenosi się poza śmierć, a jednocześnie wyzwala się z pragnienia powrotu do siebie. Jest to poziom miłości i płodzenia, na którym podmiot, kochając i płodząc, ustanawia się w szczególny sposób $^{13}$.

Następnie myśliciel odwołuje się do swoich wcześniejszych analiz i określa charakter i warunki możliwości opisania miłości erotycznej. Przede wszystkim ta miłość jest rozkoszą czerpaną z innego. A więc w samym swoim rdzeniu jest wewnętrznie sprzeczna, jest „dwuznacznością samą"14. Rozkosz, jak pokazaliśmy wcześniej, jest źródłowym wrażeniem, samym życiem człowieka, a więc jest całkowicie własna, egoistyczna, jest zaspokajaniem potrzeby przy użyciu przedmiotów. Inny człowiek zaś jest transcendencją, objawia się jako inny, i ta inność jest absolutnie nieredukowalna. Miłość jest „prawie sprzecznym rozkoszowaniem się bytem transcendentnym" ${ }^{\prime 15}$.

Lévinas wielokrotnie podkreślał, że - jako rozkosz - relacja erotyczna jest znacząca sama z siebie. Konceptualna interpretacja relacji i rozkoszy

12 Relacja erotyczna spełnia się w dotyku, m.in. pieszczocie. Tutaj zajmiemy się wyłącznie analizami Lévinasa. W następnych dziesięcioleciach pojawiła się cała seria tekstów filozoficznych podejmujących refleksję nad dotykiem. Wśród najważniejszych jest komentarz do tekstów Jeana Luca Nancy'ego: Jacques Derrida, Le Toucher, Jean-Luc Nancy, Paris 2000. Przestudiowane tego nurtu, czyli według określenia Derridy: haptocentrycznej metafizyki z perspektywy teologii katolickiej, jest osobnym, obszernym zadaniem badawczym. Trzeba tu również odnotować, że teksty Lévinasa o relacji erotycznej i pieszczocie bywają uznawane, zwłaszcza przez komentatorki, za jedne z najsłabszych w Całości i nieskończoności. Zob. np. K. Morajko, Myśl, która myśli więcej niż myśli? Emmanuel Lévinas, Całość i nieskończoność. Esej o zewnętrzności, „Principia” 24-25 (1999), s. 279-288, http:// www.guczalska.pl/teksty-akademickie/mysl-ktora-mysli-wiecej-niz-mysli-levinas.html (3.07.2019). Nie podzielam tej krytycznej oceny. Prawie na pewno ma ona związek z poglądami Lévinasa na męskość i kobiecość, które są znacząco odmienne od dominujących we współczesnym feminizmie.

13 E. Lévinas, Całość i nieskończoność..., dz. cyt., s. 305.

14 E. Lévinas, Całość i nieskończoność..., dz. cyt., s. 307.

15 E. Lévinas, Całość i nieskończoność..., dz. cyt., s. 307. 
erotycznej jest wtórna. To nie refleksja nadaje znaczenie, ale refleksja odkrywa tylko to, co jest wcześniejsze. Relacja erotyczna w swej zmysłowości jest od razu ludzka. Nie jest to „zwierzęcość” przetworzona przez rozumność. Tu właśnie najmocniej dochodzi do głosu ten cielesny, zmysłowy wymiar antropologii Lévinasa: człowiek nie jest duchem w zwierzęcym ciele. Wspólna ze zwierzętami, biologia, fizjologia, zmysłowość jest jednak w ciele człowieka całkowicie ludzka. Jest w niej nasze człowieczeństwo. Filozof przyjmuje optykę przeciwną optyce freudowskiej. „Poza twarzą” nie oznacza sfery niższej, z ukrycia rządzącej tym, co wyższe (id modelujące ego i superego). Zespolenie erotyczne w całej swej zmysłowości i fizjologii jest proste, bez podstępu. Jest odmienne i jednocześnie powiązane z twarzą. Naturę tego związku dobrze opisuje zdanie: „możliwość czerpania z Innego rozkoszy sytuuje mnie jednocześnie poniżej i powyżej mowy" ${ }^{16}$.

Można także przedstawić długą listę przeciwieństw tej wizji erotyki i koncepcji greckich, zwłaszcza stoickich, z których obficie czerpie katolicka teologia moralna, ale wykracza to poza zamysł niniejszego tekstu. Teksty Lévinasa o erotyce, podobnie jak prawie wszystkie jego teksty, otwierają liczne ścieżki interpretacyjne, możliwości podążania myśli w różnych kierunkach. Dlatego trzeba wybierać, a więc porzucać większość z otwartych dróg myślenia, tematów. Swoje opisy fenomenologiczne relacji erotycznej i pieszczoty filozof prowadzi z pozycji mężczyzny. Jest mężczyzną i choć oczywiście nie ma tu śladu mówienia $\mathrm{w}$ pierwszej osobie liczby pojedynczej, te opisy czerpią z osobistego doświadczenia, a jego osobiste doświadczenie jest doświadczeniem mężczyzny, który opisuje relację erotyczną z kobietą. Tu otwiera się droga lektury wydobywającej jego rozumienie męskości i kobiecości. Tę drogę zostawiamy $\mathrm{z}$ boku ${ }^{17}$. Otwierają się także kwestie związane z etyką, moralnością. Do nich wrócimy w ostatniej części artykułu. Tutaj chcemy skoncentrować się tylko na jednej sprawie: relacji ero-

16 E. Lévinas, Całość i nieskończoność..., dz. cyt., s. 307.

17 Nie podejmujemy także analizy dialektyki potrzeby i pragnienia ujawniającej się w zbliżeniu erotycznym, choć rozróżnienie potrzeby i pragnienia jest ważnym wątkiem myśli Lévinasa. 
tycznej w jej rozkoszy i zmysłowości, jako relacji pierwotnie społecznej, międzyludzkiej.

Lévinas stwierdza, że „miłość nie daje się prawdziwie wypowiedzieć ani w języku erotycznym czyniącym z niej zmysłowe doznanie, ani w języku duchowym, przekształcającym ją w pragnienie transcendencji"18. On sam podejmuje ryzykowną próbę opowiedzenia w języku fenomenologii o miłości, doznaniu erotycznym, pieszczocie. Jak już wspomnieliśmy, nie wszyscy komentatorzy uznali efekt tej próby za dobry. Ale ktokolwiek bierze się za pisanie o tej sferze życia ludzkiego, wchodzi na kruchy lód. Z opisów Lévinasa wybieramy i podajemy tutaj jeden dłuższy cytat, fenomenologię pieszczoty:

Pieszczota, jako dotyk, jest doznaniem zmysłowym. A jednak transcenduje zmysłowość. Nie w tym sensie, że czuje więcej, niż mogą czuć zmysły, że żywi się jakimś wzniosłym pokarmem, zachowując intencję głodu, który szuka przyobiecanego mu pożywienia i syci się nim, ale który tylko się w ten sposób pogłębia, jakby pieszczota żywiła się własnym głodem. Pieszczota niczym się nie żywi, lecz przyzywa to, co nieustannie wymyka się jej dotykowi - co wymyka się ku przyszłości, która nigdy nie jest dość przyszła, co się nieustannie ukrywa, jakby jeszcze nie istniało. Pieszczota szuka, myszkuje. Nie jest intencjonalnością odsłaniającą, lecz poszukującą: zmierza ku niewidzialnemu. W pewnym sensie wyraża miłość, ale cierpi na niemożność jej wypowiedzenia. W nieustannym narastaniu głodu odczuwa głód samej tej ekspresji ${ }^{19}$.

Trudno ten tekst analizować, rozbierać na czynniki pierwsze. Komentuje on intymną ludzką aktywność i wydobywa z pierwotnej prostoty jej ludzki i międzyosobowy charakter. Jest zupełnym przeciwieństwem traktowania pieszczoty jako tylko dotyku, tylko zmysłowości, rozumianej jako coś niskiego, wspólnego człowiekowi i zwierzętom.

18 E. Lévinas, Całość i nieskończoność..., dz. cyt., s. 307.

19 E. Lévinas, Całość i nieskończoność..., dz. cyt., s. 310. 


\section{Konkluzje: dwa paradygmaty, dwie antropologie, konsekwencje etyczne i teologiczne}

Główną tezą Lévinasa, którą tutaj staraliśmy się przedstawić, jest twierdzenie, że relacja erotyczna jest w swej zmysłowości, niemal fizjologiczności, jest relacją pierwotnie ludzką, a nie wtórnie interpretowaną jako relacja międzyludzka. Tego ludzkiego wymiaru nie otrzymuje od refleksji. Otrzymujemy go od zmysłowości, w samym drżeniu rozkoszy erotycznej. Ta rozkosz jest relacją poza twarzą, jednocześnie poniżej i ponad twarzą. W pytaniu o bezcielesną obecność w grach elektronicznych, o podmiot i naturę doznań zmysłowych wirtualnie zapośredniczonych zawarte jest pytanie o możliwość odtworzenia doznań cielesnych, zmysłowych, w sposób sztuczny. Refleksja Lévinasa wskazuje, że jest to fundamentalnie niemożliwe. Dotyk maszyny, sztucznej skóry, choćby doskonale wykonany pod względem fizjologii i mechanicznej strony odczuwania zmysłowego, jest czymś zupełnie różnym od erotycznego dotyku skóry Innego człowieka. Doznania erotyczne wzbudzane przez cokolwiek innego niż kochany-pożądany człowiek są tylko symulacrum, pasożytującym na potencjale erotyki, na erotyczności, która spełnić się może jedynie w relacji międzyludzkiej. Sztuczne doznanie $\mathrm{z}$ tego potencjału czerpie, ale $\mathrm{z}$ istoty pozostaje czymś zupełnie innym.

Należy mówić o dwóch paradygmatach myślenia, które mogą wskazywać na dwa istniejące obok siebie sposoby poznania, a nawet dwa światy: jeden, opisywany przez Lévinasa: ludzki, międzyludzki, w którym przedmioty istnieją i są poznawane tylko wtórnie, jako otoczenie, o tyle, o ile są dla nas. Drugi: świat obiektywny, opisywany przez naukę, konstruowany przez technikę, w którym człowiek poznaje i rozumie siebie poprzez obiektywność, jako część tego świata podlegającą w całości jego prawom. Taki dualizm nie może zostać uznany za ostateczny, nie można uznać istnienia dwóch, równoległych sfer rzeczywistości. Również w warstwie poznawczej taki dualizm nie jest kompromisem, który kogokolwiek zadowoli. Nauka nowożytna nie uznaje prawomocności poznania, a w konsekwencji realności istnienia 
świata, który opisuje Lévinas. On natomiast pisze o wtórności poznania naukowego, w tym matematycznego, w stosunku do poznania zmysłowego. Stwierdza: „Rzeczywistość opisywana w naukach fizyko-matematycznych zawdzięcza swój sens operacjom, które wychodzą od świata zmysłowego"20. A więc poznanie naukowe, jako wtórne, nie ma w sobie żadnego kryterium oceny wrażenia zmysłowego. Jest w stanie docierać do niego jedynie z zewnątrz, samo mając za podstawę, dla niego niewidzialną, jakby zapomnianą, pierwotne wrażenia zmysłowe. Żaden wynik badań naukowych nie jest wystarczająco mocny, by był w stanie podważyć pierwotność wrażenia zmysłowego. Jak widać, dyskusja polegająca na przeciwstawianiu sobie nawzajem argumentów nie jest łatwa.

Ze strony filozofii pozostaje siła perswazji słowa, opisu fenomenologicznego pokazującego ludzkie doświadczenie siebie, który to opis pozwala nam, o ile pójdziemy za jego analizami, głębiej przemyśleć i nazwać zmysłowość, sensualność, cielesność jako istotną składową naszego człowieczeństwa. Refleksja Lévinasa pozwala nam zwrócić uwagę na to, co samo w sobie jest wcześniejsze od naszego zwrócenia uwagi, czyli intencjonalności: Jestem człowiekiem, czyli jestem swoim ciałem zmysłowym, które posiadam. Dotyk innego człowieka jest pełnoprawną, pierwotną, czyli niewyprowadzaną z innej, jakoby bardziej „ludzkiej” relacji, relacją międzyludzką. Nie wymaga wytłumaczenia, aby „znaczył” w swojej bezznaczeniowości. Dotyk innego człowieka jest także istotowo różny od dotyku przedmiotu.

Te dwa opisane tu sposoby poznania raz po raz odsyłają do pytania o antropologię. A rozważanie istoty rozkoszy erotycznej, pieszczoty, czy po prostu dotyku innego człowieka, jest bardzo dobrym sposobem lepszego zrozumienia sporu dwóch już wspomnianych na początku artykułu antropologii: pokartezjańskiej, ściśle powiązanej z współczesną mentalnością naukową, sprowadzającej fizyczny wymiar człowieczeństwa do punktu styku z cielesnością i traktującej ciało ludzkie jako po prostu podległą prawom fizyki materię, oraz starotestamentalnej, 
uznającej człowieka za ciało ożywione duchem przenikającym każdą jego komórkę. To ciało, choć podlega prawom fizyki, jest przede wszystkim ciałem ludzkim, zmysłowością, człowieczeństwem. Chrześcijaństwo stoi po stronie tej drugiej antropologii, choć jej przyjęcie wcale nie jest tożsame z przyjęciem wiary chrześcijańskiej. Wielu niechrześcijan na świecie przyjmuje właśnie taką antropologię. Jednak wielu moich kolegów teologów i kaznodziei nie widzi nic niestosownego w stosowaniu komputerowej metafory: dusza - software, ciało - hardware, jakby nie dostrzegało jej rujnujących konsekwencji. Jestem tym nieodmiennie i niemile zaskoczony.

Logika każdej z tych antropologii z łatwością przenosi się na płaszczyznę etyczną. Dlatego tak bezproblemowo współcześnie traktuje się erotykę jako fizjologię, a jej rozkosz jako miłe doznanie, które wymaga tylko formalnego uzgodnienia interesów i zgody obu zainteresowanych stron. Wewnątrz pokartezjańskiej antropologii nie sposób znaleźć dobrego, mocnego uzasadnienia wyjątkowości erotyki i związanych z nią przykazań. Natomiast erotyka przedstawiona $\mathrm{w}$ analizach Lévinasa, umieszczona w perspektywie jego antropologii, taką etyczną perspektywę zawiera w swoim rdzeniu. Aby lepiej pokazać tę perspektywę, należy przypomnieć podstawową strukturę myśli tego filozofa. Otóż ta myśl jest zwykle charakteryzowana przy użyciu formuły: etyka poprzedza ontologię. Jest to formuła trafna, ale domagająca się dopowiedzenia. Etyczność myśli Lévinasa w żaden sposób nie koncentruje się na prawie i przykazaniach. Warstwa normatywna jest dla niego całkowicie wtórna. Nawet o Dekalogu napisał, że jest to „tekst drugorzędny”21. Etyką rozumianą jako pytanie o normy Lévinas w zasadzie się nie zajmuje. Istotą etyczności tej myśli jest Inny, jego prośba, żądanie, ubóstwo. Samo pojawianie się drugiego człowieka stawia mnie w sytuacji odpowiedzialności, która jest wcześniejsza od wszelkiej mojej zgody, której nie wybieram i od której nie mogę się uchylić. Również bliskość erotyczna dzieje się wewnątrz tej logiki: „pod innością erotyczną kryje się inność jeden-za-drugiego, 
odpowiedzialność poprzedzająca erotykę"22. W bliskości erotycznej, w pieszczocie jest nieusuwalnie obecna odpowiedzialność za bliźniego. Twarz bliźniego wzywa do odpowiedzialności za niego, a zbliżenie erotyczne i dotyk skóry w pieszczocie jest bliskością o tej samej strukturze, dzieje się wewnątrz logiki odpowiedzialności, od której nie mogę się uchylić, bo jest wcześniejsza od wszelkiej umowy i od jakiejkolwiek mojej zgody.

Chrześcijańska teologia moralna niemal od początku, a już w całej pełni od Augustyna, uwikłana jest w myśl, że zbliżenie erotyczne jest złe samo w sobie, nieczyste i potrzebuje usprawiedliwienia, zewnętrznej racji, która zniesie jego wewnętrzną nieczystość. To dziedzictwo utrudnia dzisiaj mocne przekonujące nauczanie o wymogach moralnych dotyczących seksualności człowieka. Odrzucenie utożsamienia relacji erotycznej jako takiej z grzesznością i przywrócenie pierwotnej dobroci w ocenie tej relacji jest ważnym zadaniem dla teologii moralnej. Ale ta dobroć erotyki musi zostać radykalnie przeciwstawiona postulatowi neutralności etycznej, potraktowania erotyki jako czystej fizjologiczności, do jakiej chce sprowadzić seksualność współcześnie dominująca mentalność. Wolno sądzić, że myśl Lévinasa może posłużyć w tym dziele jako ancilla theologiae.

\section{Bibliografia}

Derrida J., Le toucher, Jean-Luc Nancy, Paris 2000.

Lévinas E., Całość i nieskończoność: esej o zewnętrzności, tłum. M. Kowalska, Warszawa 1998.

Lévinas E., Inaczej niż być lub ponad istota, tłum. P. Mrówczyński, Warszawa 2000.

Lévinas E., Trudna wolność: eseje o judaizmie, tłum. A. Kuryś, Gdynia 1991.

Morajko K., Myśl, która myśli więcej niż myśli? Emmanuel Lévinas, Całość i nieskończoność. Esej o zewnętrzności, „Principia” 1999 nr 24-25, s. 279-288.

22 E. Lévinas, Inaczej niż być lub ponad istotą, dz. cyt., s. 150. Tutaj Lévinas daje kolejne opisy fenomenologiczne pieszczoty ukazujące jej nierozerwalny związek z biedą i bezbronnością nagości. 


\section{Abstrakt \\ Zagadnienie cielesności w ujęciu Emmanuela Lévinasa: rozkosz erotyczna i pieszczota}

Lévinas opisuje zbliżenie i rozkosz erotyczną jako analogiczne do spotkania człowieka objawiającego się w twarzy Innego. To zbliżenie realizujące się w pieszczocie jest rozkoszą. Rozkosz jest przez Lévinasa traktowana jako podstawowy sposób istnienia człowieka, jako pierwotne doznanie siebie samego, wcześniejsze i odrębne od intencjonalności. Ta myśl filozofa uwyraźnia to, jak bardzo wrażenie zmysłowe jest w istocie ludzkie, a przede wszystkim jak specyficznie ludzka jest zmysłowość erotyki, która jest zmysłowością bliskości z innym człowiekiem, oraz to, jak jest odmienna od wrażeń wywołanych przez jakikolwiek sztuczny impuls. Ta różnica dotyczy całej cielesności człowieka. Ciało ludzkie i jego zmysłowość nie są po prostu materią i impulsami. Takie ujęcie erotyki i cielesności pozwala zobaczyć dwa paradygmaty poznania rzeczywistości i dwie antropologie oraz wskazać możliwość odwołania się do cielesnej, zmysłowej antropologii Lévinasa w teologii moralnej w celu pokazania etycznego wymiaru zbliżenia erotycznego.

\section{Słowa kluczowe}

Lévinas, zmysłowość, erotyka, antropologia, teologia moralna

\section{Abstract \\ Embodiment According to Emmanuel Lévinas: Erotic Pleasure and Caress}

Lévinas describes erotic close-up and pleasure as analogous to meeting a man appearing in the face of another. This rapprochement realized in the caress is a delight. Pleasure is treated by Lévinas as a basic way of human existence, as a primary experience of himself, earlier and separate from intentionality. This thought of Lévinas makes it clear how sensual the sensation is in fact human, and above all how specific human the sensuality of eroticism, which is the sensuality of intimacy with another human being, and how different it is from sensations caused by any artificial impulse. This difference applies to all human corporeality. The human body and its sensuality are not simply matter and impulses. This approach 
to eroticism and corporeality allows us to see two paradigms of knowledge of reality and two anthropologies, and indicate the possibility of referring to Lévinas' bodily, sensual anthropology in moral theology in order to show the ethical dimension of erotic approach.

\section{Keywords}

Lévinas, sensuality, erotica, anthropology, moral theology 